\title{
Feasibility Studies on Static Pile Co Composting of Organic Fraction of Municipal Solid Waste With Dairy Waste Water
}

\author{
Manjula Gopinathan ${ }^{1}$, Meenambal Thirumurthy ${ }^{2}$ \\ ${ }^{1}$ Department of Civil Engineering, Karpagam University, Coimbatore 641021, India \\ ${ }^{2}$ Department of Civil Engineering, Government College of Technology, Coimbatore 641013, India \\ crossref http://dx.doi.org/10.5755/j01.erem.60.2.963
}

(received in December, 2011, accepted in June, 2012)

\begin{abstract}
Milk processing consumes a large amount of water and generates 6-10 liters of effluent per liter of milk processed. An effluent volume is approximately four times the volume of processed milk. Since the pollutants generated by industry are great losses of production, improvements in production efficiency are recommended to reduce pollutant loads. In this research a series of experimental studies were conducted with regard to bioconversion of organic fraction of municipal solid waste along with dairy waste water at different $\mathrm{C} / \mathrm{N}$ ratios. About $50 \mathrm{~kg}$ of shredded waste containing dairy waste water, saw dust, and organic fraction of municipal solid waste was placed in static piles of different proportions and $500 \mathrm{ml}$ of effective microorganisms was added to them. The variation in physical and chemical parameters was monitored throughout the process. Results indicate that co composting of dairy waste water with municipal solid waste produces compost that is more stable and homogenous and can be effectively used as soil conditioner.
\end{abstract}

Key words: Municipal solid waste, effective microorganisms, static pile composting, dairy waste water.

\section{Introduction}

The dairy industry involves processing raw milk into products such as consumer milk, butter, cheese, yogurt, condensed milk, dried milk (milk powder), and ice cream, using the processes such as chilling, pasteurization, and homogenization. Typical byproducts include buttermilk, whey, and their derivatives. The effluent is organic, slightly alkaline, but becomes acidic due to decomposition of lactose into lactic acid, followed by precipitation of casein into a highly odoriferous black sludge. When discharged into water body, especially a stagnant one, the effluent brings about rapid depletion of the dissolved oxygen, adversely affecting its ecosystem. Dairy effluents contain dissolved sugars and proteins, fats, and possible residues of additives. The key parameters are biochemical oxygen demand (BOD), with an average ranging from 0.8 to 2.5 kilograms per metric ton $(\mathrm{kg} / \mathrm{t})$ of milk in the untreated effluent; chemical oxygen demand (COD), which is normally about 1.5 times the BOD level; total suspended solids, at 100-1,000 milligrams per liter (mg/l); total dissolved solids: phosphorus (10-100 $\mathrm{mg} / \mathrm{l})$, and nitrogen (about $6 \%$ of the BOD level). Cream, butter, cheese, and whey production are major sources of BOD in effluents. The waste load equivalents of specific milk constituents are:

$1 \mathrm{~kg}$ of milk fat $=3 \mathrm{~kg} \mathrm{COD}$;

$1 \mathrm{~kg}$ of lactose $=1.13 \mathrm{~kg}$ COD; and

$1 \mathrm{~kg}$ protein $=1.36 \mathrm{~kg}$ COD.

Pretreatment of effluents comprises screening, flow equalization, neutralization, and air flotation (removing of fats and solids); it is normally followed by biological treatment. If space is available, land treatment or pond systems are potential treatment methods. Other possible biological treatment systems include trickling filters, rotating biological contactors, and activated sludge treatment. The wastewater may contain pathogens from contaminated materials or 
production processes. Hence, an effective biological treatment process such as composting is required to mitigate organic load on water bodies. Rapid urbanization has led to overstressing urban infrastructure services including municipal solid waste management because of poor resources (Akolkar A.B 2005). Tamilnadu is one among the most urbanized states in India with $43.86 \%$ of state population living in urban areas. The rate of urbanization in Tamilnadu has doubled from $22 \%$ in 1961 to the present level in 2001(CPHEEO 2000). The organic fraction of municipal solid waste can be beneficially used by co-composting with dairy waste water. The composting process is one of the bestknown processes for biological stabilization of solid organic wastes by transforming them into a safer and more stabilized material that can be used as a source of nutrients and soil conditioner in agricultural applications (Michel et al. 1996). To achieve a successful composting, the influencing factors such as temperature, moisture content, aeration, $\mathrm{pH}, \mathrm{C} / \mathrm{N}$ ratio, and composting mixtures should be appropriately controlled (Mengchun Gao et al. 2010).

\section{Materials and Methods}

\subsection{Waste Characteristics}

The study was conducted at the Vellalur Composting yard of Coimbatore corporation, Coimbatore, India. In this study, different ratios of waste mixtures and sawdust, as required for individual trials, amounting to approximately $50 \mathrm{~kg}$ for each mix ratio, were placed in 12 heaps and mixed together. The static pile was placed on the appropriate sloping concrete floor for drainage. The effective length of the pile was $0.6 \mathrm{~m}$ with a width and height of $0.5 \mathrm{~m}$ or 0.3 $\mathrm{m}$, respectively. The organic fraction of MSW was collected from Vellalore municipal composting yard and saw dust from saw mills near Kinathukadavu, Coimbatore. Dairy sludge was obtained from Aavin dairy farm, Perur. The substances were manually mixed in different proportions with an addition of effective micro-organisms as indicated in Table 1 and turned into piles.

Turning was uniformly done with the help of a wooden rod on alternate days to provide the air for microbes digesting the organics (Mazumdar N B et al. 2007). The major composition of the waste included vegetable and fruit waste. A $500 \mathrm{ml}$ solution of effective micro-organisms including Phospobacteria, Azospirillum lipoferum, Acetobacter aerogens, Trichodema viridi was added to the reactors during loading. That was the quantity of EM solution per the compost yard recommended by technical regulations for composting $50 \mathrm{~kg}$ of organic waste. Since the solution was prepared at the very yard, it was also economically feasible. $2000 \mathrm{ml}$ of deionized water was also initially added and those reactors were watered on alternate days to keep the moisture level at an optimum range from $55 \%$ to $60 \%$ (Salakinkop S R et al. 2008). The final compost in reactors was reevaluated for its stability based on the temperature, $\mathrm{pH}$, color and odor, $\mathrm{C} / \mathrm{N}$ ratio at the end of 30 days of composting. The results are tabulated in Table 2.

Table 1.

Mixture Specification

\begin{tabular}{|c|c|c|c|c|c|c||}
\hline Pile & Ratio & Saw dust (kg) & MSW(Kg) & Dairy Sludge(ml) & EM(ml) & Water(ml) \\
\hline A & $1: 3^{*}$ & 12.5 & 25 & 12.5 & 500 & 2000 \\
\hline B & $1: 6^{*}$ & 7 & 25 & 18 & 500 & 2000 \\
\hline C & $1: 9^{*}$ & 5 & 25 & 20 & 500 & 2000 \\
\hline
\end{tabular}

*Saw dust: (OFMSW+ Dairy sludge)

\section{Results and Discussion}

Initial characteristics and their variation of in a biodegradable portion of municipal solid waste obtained from Vellalore yard, Coimbatore, are given in Table 2. Initial values of phosphorus and potassium were high, indicating high initial nutrient values in the waste. Micro-nutrients and heavy metals were also high for the waste. Initial $\mathrm{C} / \mathrm{N}$ ratio of 40.31 was suitable for the composting process. High levels of EC indicate the presence of soluble salts, and initial $\mathrm{pH}$ indicates alkaline conditions due to the alkaline nature of municipal refuse. Initial characteristics of the dairy waste water are listed in Table 3. The organic matter in the sludge indicates that it is highly biodegradable. The presence of micro-nutrients in the organic waste indicates its possible conversion into high quality compost.

\subsection{Variation in temperature}

The temperature has been widely recognized as one of the most important parameters in the composting process (Strom 1985). The rise and fall in the temperature have been found to strongly correlate with microbial activity (Tiquia et al. 1996). The temperature exceeding $55^{\circ} \mathrm{C}$ is necessary to destroy pathogens in the composting mixture for at least three consecutive days (Zhang and He 2006).

The temperature patterns of different mix ratios $\mathrm{A}, \mathrm{B}$, and $\mathrm{C}$ are presented in Fig 1. The temperature was monitored during the compost cycle on alternate days. In the first trial, OFMSW and dairy industry sludge were mixed with untreated sawdust in a ratio of 1:3 (Weight basis). Maximum temperatures in the range of 45 to $46^{\circ} \mathrm{C}$ were reached within 6 days of operation, but then declined to $29{ }^{\circ} \mathrm{C}$ at the end of the composting trial. Decline in temperature started from the 
sixth day and reached the ambient temperature levels at the end of the composting period. The decline in

temperature was more rapid in the second week.

Table 2

Initial characteristics of biodegradable municipal solid waste

\begin{tabular}{|l|l|l|l|l|l||}
\hline S.No & Parameters & Value & S.No & Parameters & Value \\
\hline 1 & N-ppm & 960 & 8 & Fe-ppm & 783.38 \\
\hline 2 & P-ppm & 2113 & 9 & Mn-ppm & 133.38 \\
\hline 3 & K-ppm & 30500 & 10 & Cu-ppm & 11.52 \\
\hline 4 & Ca-ppm & 853 & 11 & C/N & 40.31 \\
\hline 5 & Mg-ppm & 301 & 12 & $\begin{array}{l}\% \text { organic } \\
\text { carbon }\end{array}$ & 30 \\
\hline 6 & Zn-ppm & 82.69 & 13 & $\begin{array}{l}\text { Ec } \\
\text { mhos/cm }\end{array}$ & 1.550 \\
\hline 7 & pH & 9.43 & \multicolumn{4}{l}{} \\
\hline
\end{tabular}

Table 3.

Initial characteristics of dairy waste water

\begin{tabular}{|c|l|c|}
\hline SI.No & NAME OF THE PARAMETERS & Value \\
\hline 1 & Temperature $\left({ }^{0} \mathrm{C}\right)$ & 20.6 \\
\hline 2 & $\mathrm{pH}$ & 6.13 \\
\hline 3 & Electrical Conductivity $(\mathrm{dS} / \mathrm{m})$ & 0.219 \\
\hline 4 & Total Dissolved Solids $(\mathrm{ppm})$ & 610 \\
\hline 5 & Chemical Oxygen Demand $(\mathrm{mg} / \mathrm{l})$ & 1400 \\
\hline 6 & Biological Oxygen Demand $(\mathrm{mg} / \mathrm{l})$ & 280 \\
\hline 7 & Phosphates $(\%)$ & 0.401 \\
\hline 8 & Potassium $(\%)$ & 1.9 \\
\hline
\end{tabular}

In the second trial, OFMSW and dairy industry sludge were mixed with untreated sawdust in a ratio of 1:6 (Weight basis). Maximum temperatures in the range of approximately 48 to $53^{\circ} \mathrm{C}$ were reached within 8 days of operation, but then declined very slowly in a range of 27 to $28^{\circ} \mathrm{C}$ at the end of the composting trial. Decline in temperature started from the eighth day and reached the ambient temperature levels at the end of the trial.

In the third trial, OFMSW and dairy industry sludge were mixed with untreated sawdust in a ratio of 1:9 (Weight basis). Maximum temperatures in the range of approximately 57 to $62^{\circ} \mathrm{C}$ were reached within 8 days of operation. The temperature in the pile remained above $40^{\circ} \mathrm{C}$ for most of the initial part of the composting trial. There was a decline in the temperature to about $38^{\circ} \mathrm{C}$ and rapidly reached the ambient temperature levels after 20 days.

The comparison of temperature variations in the piles $\mathrm{A}, \mathrm{B}$, and $\mathrm{C}$ reveals that the highest temperature of $62^{\circ} \mathrm{C}$ in the thermophilic range was reached in Pile $\mathrm{C}$ on the eighth day of composting and it was maintained over the ambient levels for 20 days, indicating higher biodegradation levels than the other mix ratios.

During most of the test period, temperatures of the composting mass increased on the very second day. Due to quick degradation of well mixed compost by acclimated effective microorganisms, a rapid temperature increase up to $42{ }^{\circ} \mathrm{C}$ was observed in Pile C. The three mix ratios containing dairy industry sludge reached the thermophilic range during the initial phase of composting.

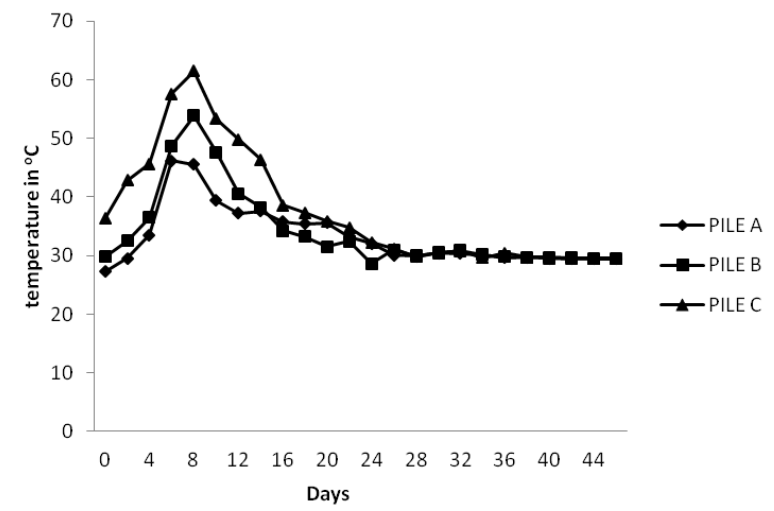

Fig. 1.

Variation of temperature during composting

\subsection{Variation in $\mathbf{p H}$}

The $\mathrm{pH}$ values of the air dried samples of the initial waste mixture for static piles $\mathrm{A}, \mathrm{B}$, and $\mathrm{C}$ were $7.03,6.65$ and 6.92 , respectively, according to the values presented in Fig.2. The $\mathrm{pH}$ value reached at the end of the composting cycle and at the level of three piles was of about 7.4 (Fig. 2). An increase in $\mathrm{pH}$ values can be considered as an indicator of maturity. Maximum value of 8.54 reached by $\mathrm{A}$ on day 16 , maximum value of 8.3 reached by $B$ and $C$ on day 18 are a result of the release of ammonia from 
ammonification and mineralization of organic nitrogen during the initial phase of composting (Wong et al. 2001). After that, the $\mathrm{pH}$ gradually decreased and stabilized in alkali values of all three composting mixtures. All the static piles have shown an increase in $\mathrm{pH}$ from the initial values and a gradual decrease to near neutral values at the end of composting due to decomposition of organic matter from OFMSW and dairy waste water.

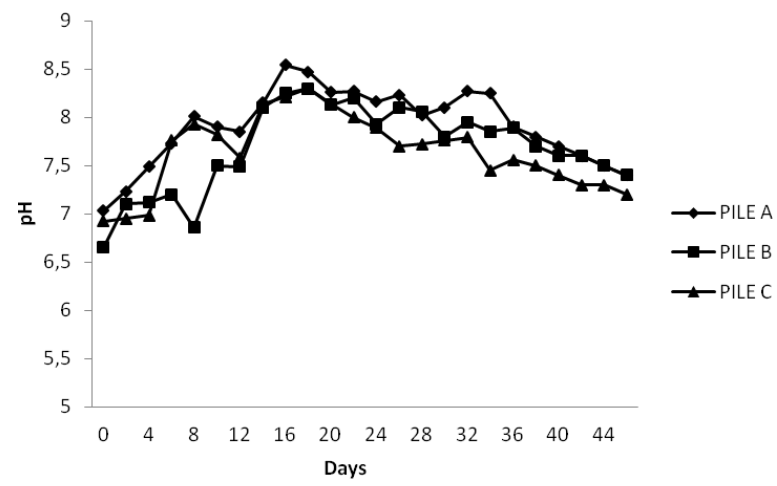

Fig. 2.

Variation of pH during composting

\subsection{Variation in pile height}

A slow settlement from an initial height of the composting mass of $26.3 \mathrm{~cm}$ to about $13.2 \mathrm{~cm}$ occurred in the pile during the completion of the test period as shown in Fig 3. The mix settlement in P2B was comparatively higher. The mix settled from initial $24.6 \mathrm{~cm}$ to $13.8 \mathrm{~cm}$ at the end of the composting period. In $\mathrm{C}$ the mix height reduced from $21.8 \mathrm{~cm}$ to $13.3 \mathrm{~cm}$. The height reductions or settlement in A, B, and C was 49.8, 43.9, and 38.99 $\%$, respectively. The settlement was higher in the mix ratio 1:3 compared to the other mix ratios with dairy sludge amendment.

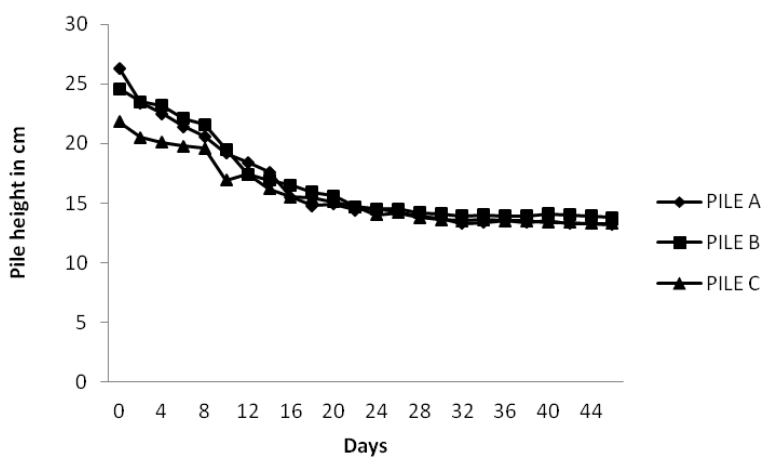

Fig. 3.

Variation of pile height during
composting

\subsection{Variation in pile weight}

The weight of the composting mixture has considerably decreased in all static piles. In $\mathrm{A}$ the weight decreased from an initial value of $56.8 \mathrm{~kg}$ to $21.6 \mathrm{~kg}$ at the end of the composting period as shown in Fig.4. Similar weight decrease in B was $53.2 \mathrm{~kg}$ to
$11.1 \mathrm{~kg}$ and in $\mathrm{C}$ the weight decrease was from 53.2 to $17.6 \mathrm{~kg}$ at the end of the composting period. The percentage weight reduction in $\mathrm{A}, \mathrm{B}$, and $\mathrm{C}$ were $61.97 \%, 79.13 \%$ and $66.91 \%$, respectively. The maximum weight reduction was observed in $\mathrm{B}$ with a mix ratio of $1: 9$

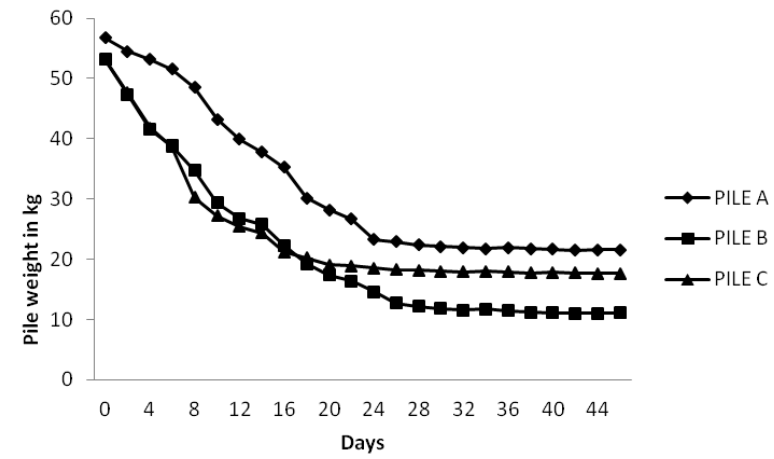

Fig. 4

Variation of pile weight during composting

\subsection{Variation in TOC}

In the first mix ratio, the composting mixture initially consisted of about $34.6 \%$ of TOC, increasing to about $41.1 \%$ at the end of 18 days, and decreasing thereafter to $27.8 \%$ at the end of 46 days, as shown in Fig.5. The composting mixture in the second mix ratio initially consisted of about $34.8 \%$ of TOC, changing to about $40.8 \%$ at the end of 14 days of active composting and decreasing gradually to $27.1 \%$ at the end of the trial. In the third mix ratio, the composting mixture initially consisted of about $29.4 \%$ of TOC, changing to about $36.9 \%$ at the end of 18 days of active composting and thereafter decreasing to $27.5 \%$ after 30 days of composting.

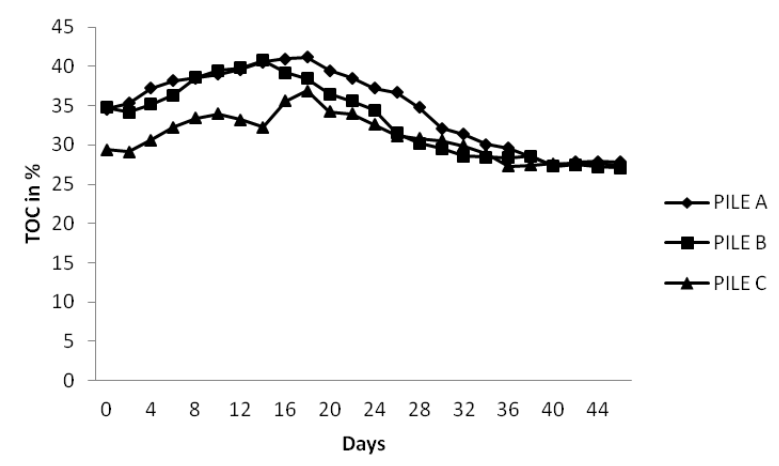

Fig. 5.

Variation of total organic carbon during composting

\subsection{Variation in EC}

Fig. 6 shows a similar pattern of change in EC for the three composting mixtures. $\mathrm{EC}$ in composting mixtures of $\mathrm{A}, \mathrm{B}$, and $\mathrm{C}$ increased from the initial 1.7, 1.8 and $2.0 \mathrm{dS} / \mathrm{m}$ to the maximum $2.6,1.5$, and 1.4 $\mathrm{dS} / \mathrm{m}$ on the $12^{\text {th }}, 14^{\text {th }}, 12^{\text {th }}$ day, respectively, followed by a gradual decrease till the end of the composting process. The initial EC increase could be caused by 
the release of mineral salts such as phosphates and ammonium ions through decomposition of organic substances. As the composting process progressed, volatilization of ammonia and precipitation of mineral salts could be the possible reasons for the decrease in $\mathrm{EC}$ at the later phase of composting. After 46 days of composting, the EC contents of the composting mixture in $\mathrm{A}, \mathrm{B}$, and $\mathrm{C}$ were $0.5,0.5$ and $0.7 \mathrm{dS} / \mathrm{m}$, respectively, which did not exceed the limit value of 3 $\mathrm{dS} / \mathrm{m}$ for stable composts.

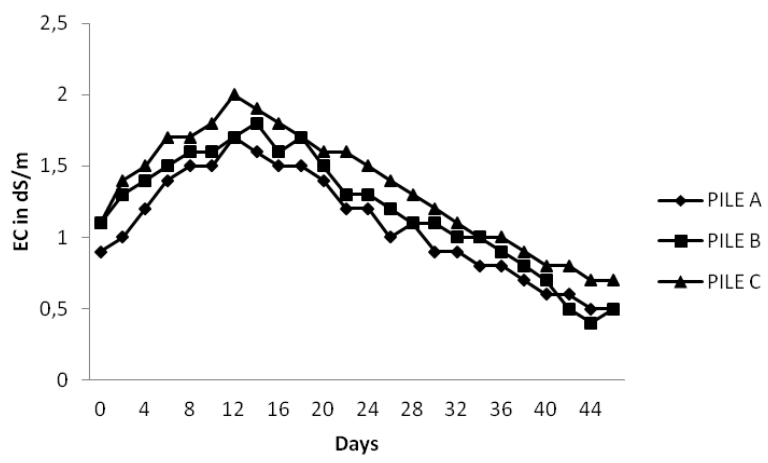

Fig. 6. Variation of electrical conductivity during composting

Table 4.

Final characteristics of compost

\begin{tabular}{||l|l|l|l||}
\hline Parameters & A & B & C \\
\hline Volatile matters \% & 33.6 & 37.5 & 45.5 \\
\hline Total organic carbon \% & 27.8 & 27.1 & 27.5 \\
\hline Total nitrogen \% & 1.41 & 1.56 & 1.53 \\
\hline C/N & 19.7 & 1.74 & 15.8 \\
\hline
\end{tabular}

Table 4 represents final characteristics of the compost after the end of the process. Then $\mathrm{C} / \mathrm{N}$ values stabilized to less than $20 . \mathrm{C} / \mathrm{N}$ values $(<25)$ at the end of the composting process indicates stability of the compost and its being within the standard limits. The values indicate that the product can be effectively used as soil fertilizer.

\section{Conclusions}

Chemical and physical characteristics of solid waste (constituents, $\mathrm{pH}$, and moisture) and operating conditions of solid waste composting (carbon-tonitrogen ratio, reaction temperature, and time) impose significant effects on the ecological succession of microorganisms, and the rate of biodegradation. The static pile composting method can be applied to domestic waste, with some alterations in the process, such as source segregation of organic and inorganic fractions of domestic waste. High organic loading on water bodies due to disposal of dairy waste water can be greatly reduced by choosing a low cost alternative such as a static pile composting method for composting dairy sludge with organic fraction of municipal solid waste.

\section{Acknowledgements}

The authors wish to acknowledge the help and support provided by the staff members of Coimbatore corporation composting yard, Coimbatore, India in carrying out this research work

\section{References}

Akolkar A.B.2000. Status of Solid Waste Management in India: Implementation Status of Municipal Solid Waste (Management and Handling) Rules , (Central Pollution Control Board, New Delhi) pp 20.

Ready Reckoner on Municipal Solid Waste Management for Urban Local Bodies 2008, (Commissionerate of Municipal Administration, Chennai), pp 16.

Manual on Municipal Solid Waste Management, 2000 (Ministry of Urban Development, Government of India, New Delhi, CPHEEO), pp 124.

Mazumdar N B, 2007.Composting municipal solid waste: the Indian Scenario, International Journal of Environmental Technology and Management,Vol. 7(3/4), pp 326-350. ISSN (Print): 1466-2132

Salakinkop S R, Hunshal C S, Gorogi P T and Basavaraj B, 2008. Studies on production and characterization of enriched urban waste composts and their influence on crops productivity, Journal of Environmental Science and Engineering, Vol .50(1), pp 83-88. ISSN 0367$827 \mathrm{X}$

Mengchun Gao, Fangyuan Liang, An Yub, Bing Li, Lijuan Yang 2010. Evaluation of stability and maturity during forced-aeration composting of chicken manure and sawdust at different $\mathrm{C} / \mathrm{N}$ ratios. Chemosphere,Vol. 78, pp 614-619. ISSN: 0045-6535

Michel, F.C., Forney, L.J., Huang, A.J., Drew, S., Czuprenski, M., Lindeneg, J.D., Reddy, C.A., 1996. Effects of turning frequency, leaves to grass ratio and windrow vs pile configuration on composting of yard trimmings. Compost Science and Utilization Vol. 4, pp 26-43. ISSN: 1065-657X

Strom, P.F., (1985). Effects of temperature on bacterial species diversity in thermophilic solid-waste composting. Applied and Environmental Microbiology .Vol. 50, pp 889-905. ISSN: 0099-2240

Tiquia, S.M., Tam, N.F.Y., (1998). Elimination of phytotoxicity during co-composting of spent pig manure sawdust litter and pig sludge. Bioresource Technology, Vol. 65, pp 43-49. ISSN: 0960-8524

Wong, J.W.C., Mak, K.F., Chan, N.W., Lam, A., Fang, M., Zhou, L.X., Wu, Q.T., Liao, X.D., (2001). Cocomposting of soybean residues and leaves in Hong Kong. Bioresource Technology.Vol 76, pp 99-106. ISSN: 09608524 
MSc Manjula Gopinathan - Department of Civil Engineering, Karpagam University, Coimbatore, India.

Main research area: solid waste management E-mail: manju_env@yahoo.com
Dr. Meenambal Thirumurthy - Department of Civil Engineering, Government college of Technology, Coimbatore, India.

Main research area: solid waste management E-mail: tmeenambal_gct@yahoo.co.in

\section{Statinès būsenos komunalinių atliekų organinès dalies ir pieninių nuotekų bendro kompostavimo galimybių tyrimas}

\section{Manjula Gopinathan ${ }^{1}$, Meenambal Thirumurthy ${ }^{2}$}

${ }^{1}$ Statybos inžinerijos katedra, Karpagam universitetas, Indija

${ }^{2}$ Statybos inžinerijos katedra, Vyriausybinè technologiju kolegija, Indija

(gauta 2011 m. gruodžio mèn., priimta spaudai 2012m. birželio mèn.)

Pieno apdirbimo pramonèje sunaudojami dideli vandens kiekiai, o vienam litrui apdirbto pieno tenka 6-10 litrų nuotekų. Nuotekų tūris yra maždaug 4 kartus didesnis nei apdirbamo pieno. Todèl vienas svarbiausių aspektų - didinti vandens naudojimo efektyvumą. Straipsnyje aprašyta daugybė tyrimų, kuriuos atliekant buvo analizuoti biologiniai kitimai maišant komunalinių atliekų biologinę frakciją su pieninès nuotekomis skirtingu anglies $\mathrm{C}$ ir azoto $\mathrm{N}$ santykiu. Maždaug $50 \mathrm{~kg}$ susmulkintų atliekų, ỉ kurių sudèti i̇eina pieninių nuotekos, pjuvenos ir organinè komunalinių atliekų dalis, buvo sukrauta $\mathfrak{i}$ krūvas ir skirtingomis proporcijomis įdedama po $500 \mathrm{ml}$ aktyviujų mikroorganizmų. Vertinti fizikinių ir cheminių parametrų pokyčiai. Rezultatai rodo, kad bendrai kompostuojant pieninių nuotekas ir komunalines atliekas pagaminamas stabilesnis ir labiau homogeniškas kompostas, kuris gali būti naudojamos kaip dirvožemio minkštiklis. 